\title{
MANAGEMENT OF ACCOUNTS RECEIVABLE OF COMPANIES IN ORDER TO IMPROVE FINANCIAL SUSTAINABILITY
}

\author{
Aigyl I. Sabirova ${ }^{1}$ \\ Andrey K. Dashin ${ }^{2}$
}

\begin{abstract}
In modern conditions, due to
customer, determine possible loan the rapid development of economic turnover, the obligation has become the most common form of civil relations. Without obligations, it is impossible to imagine the normal functioning of the economy of the state as a whole, and at the level of individual individuals and legal entities. A special place in the life amounts and loan terms for customers, etc.The article under consideration contains a description of the objects of assessment, the factual information we have collected, the stages of the analysis, the justification of the results obtained, as well as the restrictive conditions and assumptions made.
\end{abstract} of modern society is held by debt obligations. The main types of debt are receivables and payables. In an unstable market economy, the risk of nonpayment or late payment of bills increases, this leads to the appearance of the main types of debt obligations: receivables and payables. In order to manage accounts receivable, an enterprise needs to have complete information about a potential buyer, evaluate its business reputation, analyze the financial condition of each potential

Keywords: accounts receivable, credit policy, economic analysis of the company, financial results, company management, commodity credit

\section{Introduction}

Accounts

receivable significantly affect the financial position of the company, the use of cash in circulation, the amount of profit actually received in the reporting period. Since the formation of market relations in the

\footnotetext{
${ }^{1}$ Kazan Federal University, Institute of Management, Economics and Finance, Kazan, 420008, Russia. E-mail: aigylkinyes@ mail.ru. Tel: 79179350191

${ }^{2}$ Kazan Federal University, Institute of Management, Economics and Finance, Kazan, 420008, Russia. E-mail: aigylkinyes@ mail.ru. Tel: 79179350191
} 
Russian Federation is accompanied for many business entities by falling into the zone of economic uncertainty and increased risk. This requires an objective assessment of the financial condition, solvency and reliability of its business partners. You can have potentially good financial results from the sale of goods and services, but much to lose with the growth of receivables. A study of the effect of the amount and number of days on accounts receivable on the financial stability of a company is considered in detail in the scientific literature of scientists from different countries (Leila Schwab et.al, Mark Edmonds et.al), issues of corporate social responsibility and the provision of trade credit (Cheung, A.W., Pok, W.C.; Edmonds, M., Miller, T., Savage, A. Meric, G., Guner, B., Chung, S., Meric, I.). Considerable attention is paid to working capital management issues and its impact on profitability: an example of small and medium-sized enterprises (Wichitsathian, S.), client risk component assessment and corporate financial policy (Liu, LX, Mao, MQ, Nini, G.; Yao, H., Deng, Y.).

Accounts receivable can be considered in three senses:
- on the one hand for the debtor - it is a source of free funds;

- on the other hand, for the lender - this is an opportunity to increase the distribution area of its products, increase the market for the distribution of works and services;

- an aspect that is not usually advertised is a way of deferring tax payments under the "mutual debts" scheme.

In monitoring receivables, economic analysis is one of the main functions. The main tasks of economic analysis are: a qualitative assessment of the accumulated receivables and the identification of reserves for optimizing the size, structure and quality of receivables.

\section{Methodology}

We will consider in more detail the aspects of accounting for receivables for settlements with external contractors using the example of the Yamashneft Oil and Gas Production Unit. This enterprise was established in 1969 as an experimental enterprise for conducting pilot industrial development of small fields in the Republic of Tatarstan with 
hard-to-recover reserves of heavy and

highly viscous oils.

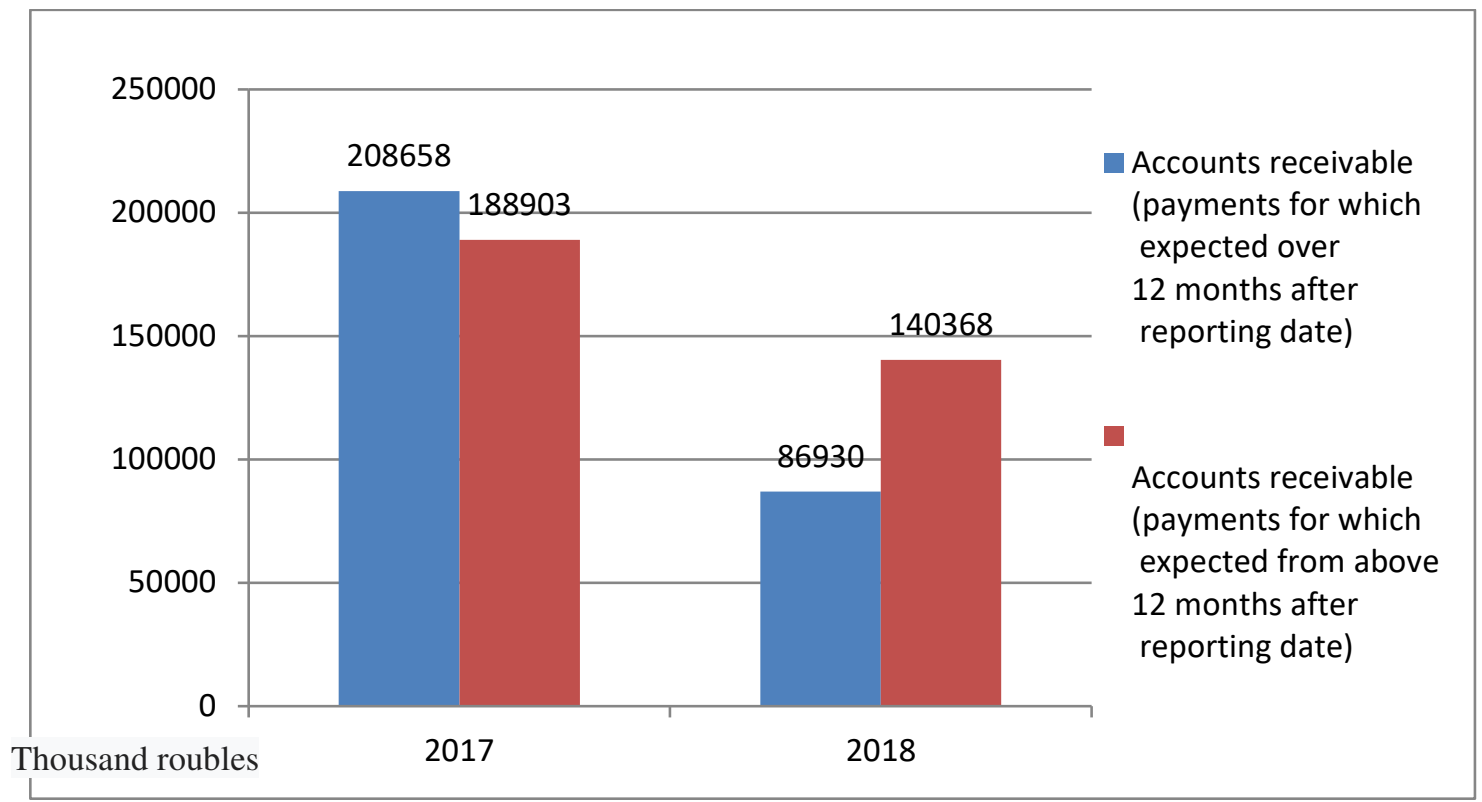

Fig. 1. Accounts receivable structure for 2017-2018 in NGDU "Yamashneft"

The share of long-term receivables in total debt in 2018 compared to 2017 decreased by $14 \%$. The share of short-term receivables in total debt in 2018 increased by $14 \%$. The reason for such structural changes lies in the change in the volume of activity, a decrease in the number of economic ties.

Table 1:The level of receivables at NGDU Yamashneft for the period 20162018

\begin{tabular}{|c|c|c|c|}
\hline \multirow{2}{*}{ ear } & $\begin{array}{c}\text { Quarter } \\
\text { No. }\end{array}$ & $\begin{array}{c}\text { Quarter in } \\
\text { order }\end{array}$ & $\begin{array}{c}\text { Accounts receivable } \\
\text { (T.RUB.) }\end{array}$ \\
\hline \multirow{3}{*}{2} & 1 & 1 & 186719 \\
\cline { 2 - 4 } & 2 & 2 & 163690 \\
\cline { 2 - 4 } 016 & 3 & 3 & 186921 \\
\hline
\end{tabular}


Periódico do Núcleo de Estudos e Pesquisas sobre Gênero e Direito Centro de Ciências Jurídicas - Universidade Federal da Paraíba V. 8 - N 06 - Ano 2019 - Special Edition ISSN | 2179-7137 | http://periodicos.ufpb.br/ojs2/index.php/ged/index

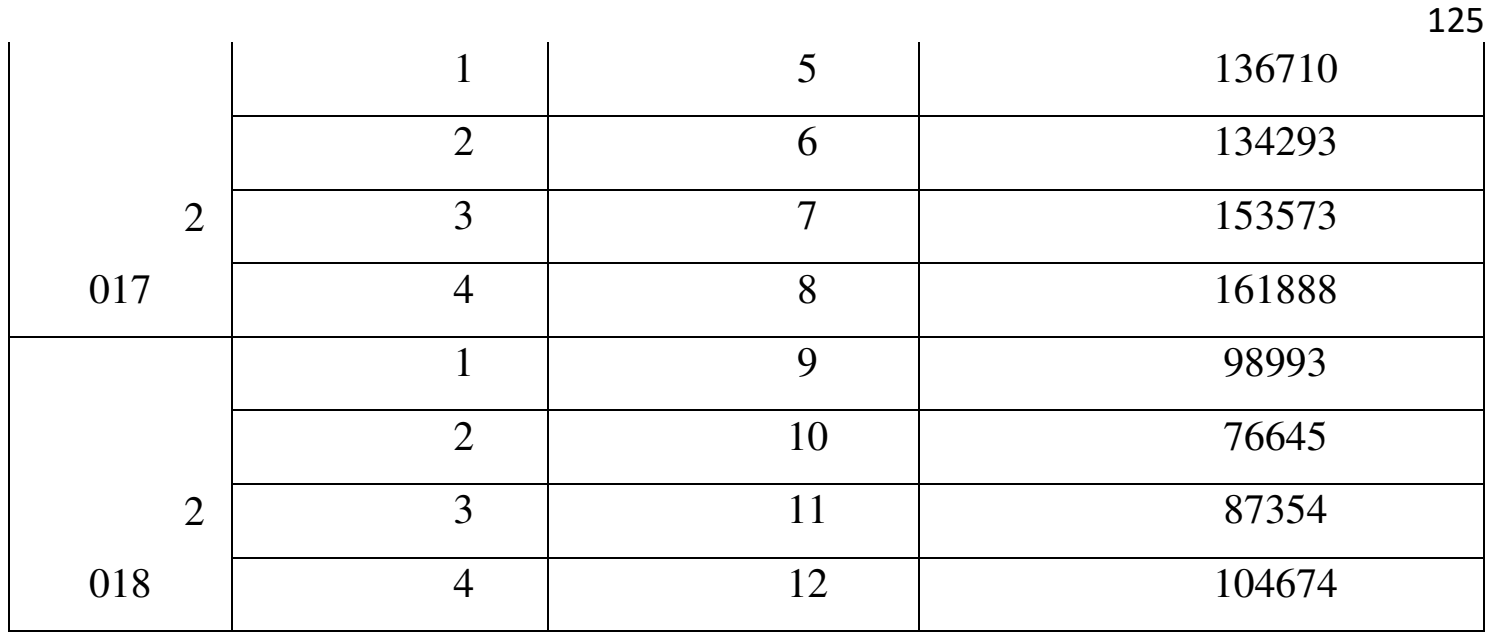

According to Figure 2, based on

the construction of the trend, the dynamics of a decrease in the amount of receivables is observed.

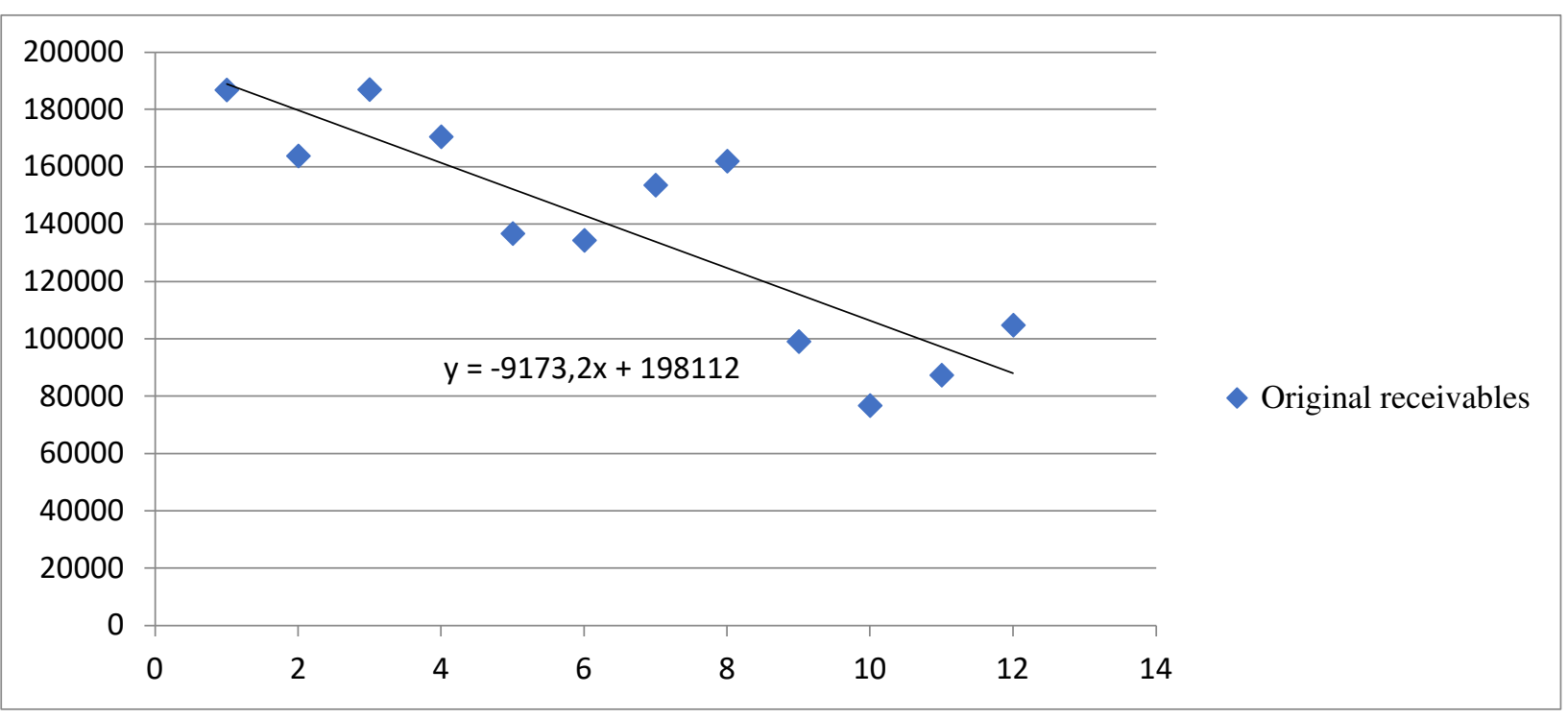

Fig. 2. The graph of the trend line and the original receivables

The amount of receivables decreases, and accordingly, the receivables turnover ratio will increase. This situation has a positive effect on the financial condition of the enterprise and the structure of its assets.
Analysis of the impact of receivables on the financial performance of a business entity should take into account the availability of available funds in circulation, which can be expressed by the inequality: 


$$
\mathrm{P}_{\mathrm{ld}} * \mathrm{C}_{\mathrm{od}}>\mathrm{P}_{\mathrm{lc}} * \mathrm{C}_{\mathrm{ok}},(1)
$$

where $\mathrm{P}_{l d}$ is the sum of one payment of debtors,

$\mathrm{P}_{\mathrm{lc}}$ - the amount of one payment to creditors,

$\mathrm{C}_{\text {od }}$ - the number of full revolutions of receivables,

$\mathrm{C}_{\mathrm{ok}}$ - the number of full turns of accounts payable.

It is necessary to apply the condition for the availability of available funds in the turnover of the Oil and Gas Production Company Yamashneft for 2018. For example, on 360 day:

$$
\begin{aligned}
& \mathrm{C}_{\mathrm{od}}=360 / 151=2, \text { and } \mathrm{C}_{\mathrm{ok}}= \\
& 360 / 366=0.984
\end{aligned}
$$

Therefore, for 360 days, the condition of inequality is met:

$202107.2 * 2>403494 * 0.984$

The amount of available funds in circulation is

$202107.2 * 2-403494 * 0.984$

$$
=7176.3
$$

A similar calculation on 365 day gives a different result:

$$
\begin{gathered}
\mathrm{C}_{\mathrm{od}}=365 / 151=2, \text { and } \mathrm{C}_{\mathrm{ok}}= \\
365 / 366=0.997 \\
202107.2 * 2>403494 * 0.997 \\
202107.2 * 2-403494 * 0.997 \\
=1931.4
\end{gathered}
$$

It is necessary to find out what affected the change in financial condition. From a comparison of the numerical inequalities corresponding to 360 and 365 days, it can be seen that the number of turns of receivables and payables remained unchanged. This suggests that the state of receivables and payables did not affect the financial result of the Yamashneft Oil and Gas Production Unit.

In practice, NGDU "Yamashneft" use a well-known rating system using liquidity ratios to evaluate buyers' credit ratings: absolute liquidity ratio (K1); critical liquidity ratio (K2); current liquidity ratio (K3), ratio of equity to borrowed funds (K4); return on sales ratio (K5), each of which has a standard value, depending on the categories of debtors:

1) first-class, the creditworthiness of which is not in doubt;

2) second-class, whose creditworthiness requires a balanced approach;

3) third-class - their creditworthiness is associated with increased risk. 
Depending on the actual values,

the indicators are divided into categories, as presented in the Table 1 .

Table 1:Categories of borrower credit rating indicators

\begin{tabular}{|c|c|c|c|}
\hline Rates & First & Second & Third category \\
\hline K 1 & 0,2 and & $0,15-0,2$ & less 0,15 \\
\hline K 2 & 0,8 and & $0,5-0,8$ & less 0,5 \\
\hline K 3 & 2,0 and & $1,0-2,0$ & less 1,0 \\
\hline K 4 & 1,0 and & $0,7-1,0$ & less 0,7 \\
\hline K 5 & 0,15 and & less 0,15 & unprofitable \\
\hline
\end{tabular}

This method of assessing creditworthiness is simple and described in detail in the literature, however, often the statements of Russian companies are significantly distorted and do not reflect the real situation, which complicates the assessment of their solvency based on financial ratios. Often, enterprises use an expert assessment technique. The company can draw information about the counterparty from any available and reliable sources of information. Employees of the company can go to a potential buyer (sometimes incognito) and evaluate the level of its prices, product range, etc. The result is the occurrence of overdue and uncollectible receivables, a slowdown in sales growth, and liquidity problems. In order to avoid these problems, it is recommended that Yamashneft Oil and Gas Company use the assessment of a credit rating using the method assuming that the counterparty's credit rating depends on the factors presented in the Table 2.

Table 2:Buyer Credit Ratings

\begin{tabular}{|c|c|c|}
\hline Factors & $\begin{array}{r}\text { Criterion } \\
\text { weight, \% }\end{array}$ & $\begin{array}{l}\text { Indicators used to measure credit } \\
\text { rating }\end{array}$ \\
\hline Legal risk & 30 & Indicators used to measure credit \\
\hline & & Form of incorporation \\
\hline
\end{tabular}




\begin{tabular}{|c|c|c|}
\hline & & $\begin{array}{l}\text { The period of existence of the } \\
\text { legal entity (debtor) } \\
\text { The period of cooperation under } \\
\text { the contract }\end{array}$ \\
\hline Operational & 40 & $\begin{array}{l}\text { Validity of the current contract } \\
\text { Customer Market Share } \\
\text { Availability of debtor strategy } \\
\text { and its transparency }\end{array}$ \\
\hline $\begin{array}{l}\text { Financial } \\
\text { risk (probability of } \\
\text { bankruptcy) }\end{array}$ & 30 & $\begin{array}{l}\text { Effective management } \\
\text { Debtor's overdue accounts } \\
\text { receivable level for the last reporting year } \\
\text { The ratio of current assets and } \\
\text { liabilities, leverage, interest coverage on } \\
\text { loans from profit }\end{array}$ \\
\hline
\end{tabular}

The weight of risk factors in assessing the credit rating of debtors should be determined by experts. The problems of receivables management faced by enterprises are quite typical:

- there is no reliable information on the maturities of obligations of companies by debtors;

- work with overdue receivables is not regulated;

- there is no data on the increase in costs associated with an increase in the size of receivables and the time of its turnover; 
debtors for whom there is an overdue

debt. Determine their credit rating (Table

$3)$.

Table 3: Credit rating of debtors of NGDU Yamashneftm

\begin{tabular}{|c|c|c|c|}
\hline $\begin{array}{l}\text { Company } \\
\text { name }\end{array}$ & $\begin{array}{r}\text { Delay } \\
\text { period, days }\end{array}$ & $\begin{array}{l}\text { Sales } \\
\text { amount for the } \\
\text { year, thousand } \\
\text { rubles }\end{array}$ & Group \\
\hline $\begin{array}{l}\text { LLC UK } \\
\text { "Tatneft- } \\
\text { Energoservice" }\end{array}$ & 50 & 10496 & $\mathrm{C}$ \\
\hline $\begin{array}{r}\text { LLC UK } \\
\text { "System-Service" }\end{array}$ & 90 & 2180 & $\mathrm{E}$ \\
\hline LLC Tatintek & 45 & 113681 & $\mathrm{C}$ \\
\hline $\begin{array}{l}\text { LLC UK } \\
\text { “TMS-Group" }\end{array}$ & 30 & 337882 & B \\
\hline $\begin{array}{l}\text { LLC “TNG- } \\
\text { Group" }\end{array}$ & 90 & 1954 & E \\
\hline
\end{tabular}

Based on the data in Table 3, we will calculate the penalties for overdue receivables for debtor groups "B" and “C”, and for group "E" we will stipulate a condition - $100 \%$ prepayment. The calculation results are presented in the Table 4.

Table 4:Calculation of Penalties

\begin{tabular}{|c|c|c|}
\hline Debtor group & Calculation & $\begin{array}{c}\text { Value } \\
\text { thousand rubles }\end{array}$ \\
\hline
\end{tabular}




\begin{tabular}{|c|c|c|}
\hline $\begin{array}{l}\text { S - LLC UK } \\
\text { "Tatneft- } \\
\text { Energoservice" }\end{array}$ & $\begin{array}{l}\text { 30days } * 1800 \text { t.rub. } * 0,02 \% \\
+20 \text { days } * 1800 \text { t.rub. } * 0,03 \%\end{array}$ & $21,6^{1}$ \\
\hline $\begin{array}{l}\text { S - Tatintek } \\
\text { LLC }\end{array}$ & $\begin{array}{l}\text { 30days } * 3942 \text { t.rub. } * 0,02 \% \\
+15 \text { days } * 3942 \text { t.rub. } * 0,03 \%\end{array}$ & 41,39 \\
\hline $\begin{array}{l}\text { B - LLC Asset } \\
\text { Management Company } \\
\text { "TMS-Group" }\end{array}$ & 30days $* 9514$ t.rub. $* 0,01 \%$ & 28,5 \\
\hline Total & - & 91,49 \\
\hline
\end{tabular}

Thus, the calculations show that for the failure to fulfill their contractual obligations, debtors will have to pay fines in the amount of 91.49 thousand rubles. In order to avoid additional obligations arising from the terms of the contracts, the debtors will be forced to pay ahead of schedule or in due time for the services rendered to them.
We determine the effect of the proposed measures in the form of calculating the turnover of receivables in case of early repayment and its impact on the release of funds as a result of accelerating the turnover of receivables. The calculation results are presented in the Table 5.

Table 5: Calculation of the effect of the proposed activities

\begin{tabular}{|c|r|r|r|}
\hline \multicolumn{1}{|c|}{ Indicator } & $\begin{array}{c}\text { Before } \\
\text { the offer }\end{array}$ & $\begin{array}{r}\text { After the } \\
\text { offer }\end{array}$ & $\begin{array}{c}\text { Rejection } \\
\text { (gr. 3-gr. } \\
\text { Overdue }\end{array}$ \\
\hline $\begin{array}{l}\text { receivables, thousand } \\
\text { rubles }\end{array}$ & 15426 & - & -15426 \\
\hline $\begin{array}{l}\text { The amount } \\
\text { of penalties, thousand } \\
\text { rubles }\end{array}$ & 91,49 & - & $-91,49$ \\
\hline
\end{tabular}




\begin{tabular}{|c|c|c|c|}
\hline $\begin{array}{l}\text { Total } \\
\text { receivables at the end } \\
\text { of } 2018 \text {, thousand } \\
\text { rubles }\end{array}$ & 227298 & 211872 & -15426 \\
\hline $\begin{array}{l}\text { The average } \\
\text { value of receivables } \\
\text { for } 2018, \text { thousand } \\
\text { rubles }\end{array}$ & 312475,2 & 304716,5 & $\begin{array}{r}- \\
10775,87\end{array}$ \\
\hline $\begin{array}{l}\text { Revenue for } \\
2018 \text {, thousand rubles }\end{array}$ & 408794 & 408794 & - \\
\hline $\begin{array}{l}\text { Accounts } \\
\text { receivable turnover, } \\
\text { turnover }\end{array}$ & 1,3 & 1,34 & 0,04 \\
\hline $\begin{array}{l}\text { The duration } \\
\text { of one turnover of } \\
\text { receivables, days }\end{array}$ & 277 & 268 & -9 \\
\hline $\begin{array}{l}\text { Amount of } \\
\text { funds released as a } \\
\text { result of acceleration } \\
\text { of receivables } \\
\text { turnover, thousand } \\
\text { rubles }\end{array}$ & & 10220 & +10220 \\
\hline
\end{tabular}

As can be seen from table 5, as a result of the implementation of the simulation model of receivables management at NGDU Yamashneft, overdue receivables in the amount of 15426 thousand rubles will be fully repaid, given the fact that enterprises will not want to pay penalties for each day of delay. As a result of this, the total annual accounts receivable turnover ratio will increase by 0.04 and the duration of one turnover of receivables will decrease by 9 days. This fact, in turn, will affect the increase in revenue from the provision of services by 10,220 thousand rubles. due 
to the acceleration of receivables turnover.

\section{Conclusion}

A detailed analysis of accounts receivable showed that financial stability indicators tend to increase due to an increase in retained earnings, the source of which is the amount of additional revenue released as a result of the acceleration of receivables turnover.

The final step in assessing a company's receivables is to evaluate the financial ratios that affect the financial position of the Yamashneft Oil and Gas Production Unit before and after the proposed measures for managing receivables, the results of which are presented in the Table 6 .

Table 6:Evaluation of the effectiveness of the implementation of the proposed activities in NGDU "Yamashneft"

\begin{tabular}{|c|c|c|c|c|}
\hline Indicator & $\begin{array}{l}\text { Units } \\
\text { rev. }\end{array}$ & $\begin{array}{r}\text { Befo } \\
\text { re the offer }\end{array}$ & $\begin{array}{l}\text { Aft } \\
\text { er the offer }\end{array}$ & $\begin{array}{l}\text { Rejecti } \\
\text { on } \\
\text { (gr. 3- } \\
\text { gr. 2) }\end{array}$ \\
\hline $\begin{array}{l}\qquad \text { Account } \\
\text { s receivable } \\
\text { turnover }\end{array}$ & $\begin{array}{l}\text { turnov } \\
\text { er }\end{array}$ & 1,3 & $4^{1,3}$ & 0,04 \\
\hline $\begin{array}{l}\text { Duration } \\
\text { of one turnover } \\
\text { of receivables }\end{array}$ & days & 277 & 268 & -9 \\
\hline $\begin{array}{l}\text { Loss of } \\
\text { core business }\end{array}$ & $\%$ & 29 & 27 & -2 \\
\hline $\begin{array}{l}\text { Ratio of } \\
\text { borrowed and } \\
\text { own funds }\end{array}$ & odds & $6^{13,8}$ & $88^{13,}$ & $+0,02$ \\
\hline
\end{tabular}




\begin{tabular}{|c|c|c|c|c|}
\hline $\begin{array}{l}\text { Coeffici } \\
\text { ent of financial } \\
\text { dependence }\end{array}$ & odds & 0,06 & $5^{0,0}$ & $-0,01$ \\
\hline $\begin{array}{l}\text { Equity } \\
\text { maneuverability } \\
\text { ratio }\end{array}$ & odds & 0,28 & $9^{0,2}$ & $+0,01$ \\
\hline
\end{tabular}

According to the results of the calculations, financial stability indicators tend to grow due to an increase in retained earnings, the source of which is the amount of additional revenue released as a result of the acceleration of receivables turnover. According to the financial results report, NGDU Yamashneft for 2018 received a loss from its main activities in the amount of 169232 thousand rubles. As a result of the proposed measures, the company will be able to reduce the loss of operations by $2 \%$ points, which indicates the effectiveness of the implementation of the receivables management system at NGDU Yamashneft.

Thus, the timely receipt of revenue from sales of products (works, services) is a guarantee of stable financing of economic activities of enterprises. Working capital at the stage of circulation, represented by receivables, significantly complicate the economic processes at the enterprise, lead to temporary or chronic insolvency caused by the lack of funds in the accounts of the business entity.

An important aspect of working capital management at a timely stage is the search for effective mechanisms for their collection in cash, that is, a clear organization of the system of settlements with partners.

\section{Acknowledgements}

The work is performed according to the Russian Government Program of Competitive Growth of Kazan Federal University.

\section{Bibliography}

Leila Schwab, Stefan Gold, Gerald Reiner Exploring financial sustainability of SMEs during periods of production growth: A simulation study // International Journal of Production 
Economics, Volume 212, June 2019, Pages 8-18

Turgel, I. D., Bozhko, L. G, \& Linshi, S. (2016). State support for single-industry towns' development of Russia and Kazakhstan. Finance: Theory and Practice, 2(92), 22-32. (In Russ.)

Safiullin, A.R., Shakirzyanov, N.R., Ravzieva, D.I. Infrastructure for regional development investment projects // Journal of Social Sciences Research 2018 (Special Issue 1), p. 281-284

Mark Edmonds, Tad Miller, Arline Savagea Accounts receivable: An audit simulation // Journal of Accounting Education Volume 47, June 2019, Pages 75-92

Ismagilov I.I., Khasanova S. F. Algorithms of parametric estimation of polynomial trend models of time series on discrete transforms / I.I. Ismagilov, S. F.Khasanova // Academy of Strategic Management Journal, Volume 15, Special Issue, 2016. - p. 21-2

Cheung, A.W., Pok, W.C. Corporate social responsibility and provision of trade credit // Journal of Contemporary Accounting and Economics 15(3), 2017. Mingazova, A.I., Khayrullina, A.D., Garipova, E.N. Contemporary economic models: Evidence from Russia // International Journal of Economic Perspectives 11(3), 2017. - p. 1858-1864

Yao, H., Deng, Y. Managerial incentives and accounts receivable management policy // Managerial Finance 2018. - 44(7), c. 865-884

Kadochnikova, E.I., Ismigilov, I.I. Measurement of cognitive growth factors of regional economy based on panel data // Mediterranean Journal of Social Sciences 5(24), - 2014 p. 377-382

Liu, L.X., Mao, M.Q., Nini, G. Customer risk and corporate financial policy: Evidence from receivables securitization // Journal of Corporate Finance 50, 2018 p. $453-467$ 